\title{
Microstructure and Mechanical Properties of Sintered Bodies of Fine Powders in $\mathrm{Si}_{3} \mathrm{~N}_{4}$-TiN System
}

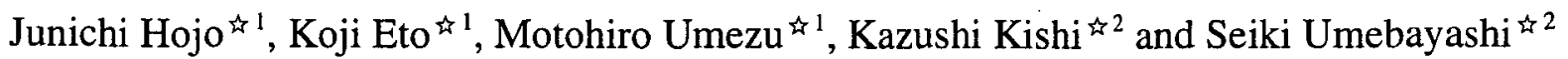 \\ ${ }^{\prime}$ 'Department of Chemistry and Biochemistry, Graduate School of Engineering, Kyushu University, 6-10-1 Hakozaki, Higashi-ku, \\ Fukuoka 812. ${ }^{2}$ Kyushu National Industrial Research Institute, Shuku-machi, Tosu 841.
}

Received September 8, 1997

\section{SYNOPSIS}

Fine $\mathrm{Si}_{3} \mathrm{~N}_{4}$ powder and $\mathrm{Si}_{3} \mathrm{~N}_{4}$-TiN composite powder were prepared by vapor phase reaction method, and hotpressed to investigate the effects of sintering condition and $\mathrm{TiN}$ inclusion on the microstructure and mechanical properties of sintered bodies. The prepared powders were fine with the size below $0.05 \mu \mathrm{m}$. Hot-pressing was conducted at $1800-1850^{\circ} \mathrm{C}$ in $\mathrm{N}_{2}(\mathrm{latm})$ with $6 \mathrm{wt} \% \mathrm{Y}_{2} \mathrm{O}_{3}$ and $2 \mathrm{wt} \% \mathrm{Al}_{2} \mathrm{O}_{3}$ as sintering aid. When fine $\mathrm{Si}_{3} \mathrm{~N}_{4}$ powder was sintered at $1800^{\circ} \mathrm{C}$, the sintered body had a fine-grained microstructure. By increase in temperature to $1850^{\circ} \mathrm{C}$, rod-like grains grew in the fine matrix, resulting in an increase in fracture toughness. Fine TiN particles were dispersed in $\mathrm{Si}_{3} \mathrm{~N}_{4}$ matrix by sintering of $\mathrm{Si}_{3} \mathrm{~N}_{4}$-TiN composite powder, indicating the formation of nanocomposite. In the composite system, the growth of rod-like grains was observed even at $1800^{\circ} \mathrm{C}$. This suggests the acceleration of $\mathrm{Si}_{3} \mathrm{~N}_{4}$ grain growth by $\mathrm{TiN}$ inclusion. The composite had a high fracture toughness.

KEY WORDS

fine powder, composite powder, silicon nitride, titanium nitride, nanocomposite

\section{INTRODUCTION}

Refractory ceramics have been developed as hightemperature engineering materials. However, the low fracture toughness and the low thermal-shock resistance limit the applications. There are two ways to improve the mechanical properties of ceramics: one is the control of microstructure and another is the fabrication of composite. Recently, the excellent mechanical properties of ceramic nanocomposites have been receiving a great attention ${ }^{1)}$. Hojo et al. have studied on the preparation of fine powders and composite powders of silicon carbide $(\mathrm{SiC})$ and silicon nitride $\left(\mathrm{Si}_{3} \mathrm{~N}_{4}\right)$ by vapor phase reaction method ${ }^{2-4)}$. The fine powder had a high sinterability ${ }^{5}$. The composite powders were useful for fabrication of nanocomposites ${ }^{4,6,7)}$.

In the present work, fine $\mathrm{Si}_{3} \mathrm{~N}_{4}$ powder and $\mathrm{Si}_{3} \mathrm{~N}_{4}$-TiN composite powder prepared by vapor phase reaction method were hot-pressed and the effects of sintering condition and TiN inclusion on the microstructure and mechanical properties of sintered bodies were investigated. $\mathrm{Si}_{3} \mathrm{~N}_{4}-\mathrm{TiN}$ composites have been investigated with emphasis on the improvement of mechanical properties and the increase of electrical conductivity of $\mathrm{Si}_{3} \mathrm{~N}_{4}$ because $\mathrm{TiN}$ is a metallic conductor $^{8-10)}$. They were fabricated by pressurelesssintering of mixed powder, or reaction sintering. On the other hand, the use of $\mathrm{Si}_{3} \mathrm{~N}_{4}$-TiN composite powder will make it possible to achieve fine dispersion of TiN particles in $\mathrm{Si}_{3} \mathrm{~N}_{4}$ matrix.

\section{EXPERIMENTAL}

\subsection{Preparation of powders}

$\mathrm{Si}_{3} \mathrm{~N}_{4}$ powder was prepared in $\mathrm{SiCl}_{4}-\mathrm{NH}_{3}-\mathrm{H}_{2}$ system and $\mathrm{Si}_{3} \mathrm{~N}_{4}$-TiN composite powder in $\mathrm{SiCl}_{4}-\mathrm{TiCl}_{4}-\mathrm{NH}_{3}-\mathrm{H}_{2}$ system. The vapor phase reaction was conducted by using a flowtype reactor consisting of an alumina reaction tube and an electric furnace as previously described ${ }^{2-4}$. Vapors of $\mathrm{SiCl}_{4}$ and $\mathrm{TiCl}_{4}$ were carried by $\mathrm{H}_{2}$. The metal chloride and ammonia were separately introduced into the reactor and mixed in the hot zone at about $1000^{\circ} \mathrm{C}$. Reaction temperature was $1400-1500^{\circ} \mathrm{C}$ at the center of furnace. The powder product included $\mathrm{NH}_{4} \mathrm{Cl}$. It was removed by sublimation at $400^{\circ} \mathrm{C}$ in $\mathrm{N}_{2}$ stream. In some experiments, the synthesized powders were heat-treated at $1000-1350^{\circ} \mathrm{C}$ for $1-2 \mathrm{~h}$ in $\mathrm{N}_{2}$. Commercial $\alpha-\mathrm{Si}_{3} \mathrm{~N}_{4}$ powder (Ube Ind. Ltd., SN-E10: particle diameter $<0.5 \mu \mathrm{m}$ ) was also used for comparison.

2.2 Sintering of powders

As sintering aid, $\mathrm{Y}_{2} \mathrm{O}_{3}(6 \mathrm{wt} \%)$ and $\mathrm{Al}_{2} \mathrm{O}_{3}(2 \mathrm{wt} \%)$ were added to the powders. A mixed sol of $\mathrm{Y}_{2} \mathrm{O}_{3}$ and $\mathrm{Al}_{2} \mathrm{O}_{3}$ was prepared by addition of $\mathrm{NH}_{4} \mathrm{OH}$ to an ethanol solution of 
$\mathrm{Y}\left(\mathrm{NO}_{3}\right)_{3}$ and $\mathrm{Al}\left(\mathrm{NO}_{3}\right)_{3}$. The sol particles were washed with ethanol to eliminate water because fine amorphous $\mathrm{Si}_{3} \mathrm{~N}_{4}$ powder was partially hydrolyzed with water. $\mathrm{Si}_{3} \mathrm{~N}_{4}$ powder and $\mathrm{Si}_{3} \mathrm{~N}_{4}$-TiN composite powder were mixed with the sol particles in ethanol, dried with a rotary evaporator, and then heat-treated at $550^{\circ} \mathrm{C}$ in $\mathrm{N}_{2}$.

Powder samples were hot-pressed into disks of $10 \mathrm{~mm}$ in diameter and about $2 \mathrm{~mm}$ thick. Hot-pressing was performed using a graphite mold painted with BN lubricant in $\mathrm{N}_{2}$ (1 atm). A rf-induction furnace was used for heating, in which the heating rate was controlled at $20^{\circ} \mathrm{C} / \mathrm{min}$ or $100^{\circ} \mathrm{C} / \mathrm{min}$ in the temperature range above $1000^{\circ} \mathrm{C}$. The temperature was kept for $2 \mathrm{~h}$ at $1800^{\circ} \mathrm{C}$ and $1850^{\circ} \mathrm{C}$. The loading pressure was $64 \mathrm{MPa}$. The surface of sintered disk was polished with $\mathrm{SiC}$ and diamond abrasives.

\subsection{Characterization of powders and sintered bodies}

Particle morphology was observed with a transmission electron microscope (TEM) or a scanning electron microscope (SEM). Crystalline phases were analyzed by $\mathrm{X}$-ray diffraction (XRD). In $\mathrm{Si}_{3} \mathrm{~N}_{4}$-TiN composite powder, the $\mathrm{Si} / \mathrm{Ti}$ atomic ratio was determined by energy dispersive $\mathrm{X}$-ray analysis (EDX) with SEM and the compositions were calculated on the assumption of stoichiometric formulas of $\mathrm{Si}_{3} \mathrm{~N}_{4}$ and $\mathrm{TiN}$.

Sintered specimens were analyzed by the Archimedes density measurement, X-ray diffraction, and SEM observation. Hardness and fracture toughness were measured by the Vickers indentation technique (load: $10 \mathrm{~kg}$ ). The fracture toughness was calculated by using Niihara's equation ${ }^{11)}$. Thermal shock resistance was evaluated by quenching method with water at room temperature, in which cracks on the disk surface were observed with an optical microscope. The test was repeated for each sample with increasing temperature at about $30^{\circ} \mathrm{C}$ interval.

\section{RESULTS AND DISCUSSION}

\subsection{Properties of synthesized powders}

Fine powders of $\mathrm{Si}_{3} \mathrm{~N}_{4}$-TiN system were formed by the vapor phase reaction method. The particle diameter was below $0.05 \mu \mathrm{m}$. TiN content was controlled in the range of $0-20 \mathrm{vol} \%$ by the concentration ratio of $\mathrm{TiCl}_{4}$ to $\mathrm{SiCl}_{4}$ in the vapor phase. XRD patterns of the synthesized powders are shown in Fig.1. The crystalline phase of $\mathrm{Si}_{3} \mathrm{~N}_{4}$ was not detected. Although XRD peaks of TiN were observed in $\mathrm{Si}_{3} \mathrm{~N}_{4}$-TiN composite powder, the peaks were very weak. These results mean that $\mathrm{Si}_{3} \mathrm{~N}_{4}$ was in an amorphous state and TiN had very small particle size or low crystallinity.

It has been already reported that fine powders of $\mathrm{Si}_{3} \mathrm{~N}_{4}$ and $\mathrm{TiN}$ were formed by vapor phase reactions of $\mathrm{SiCl}_{4-}$

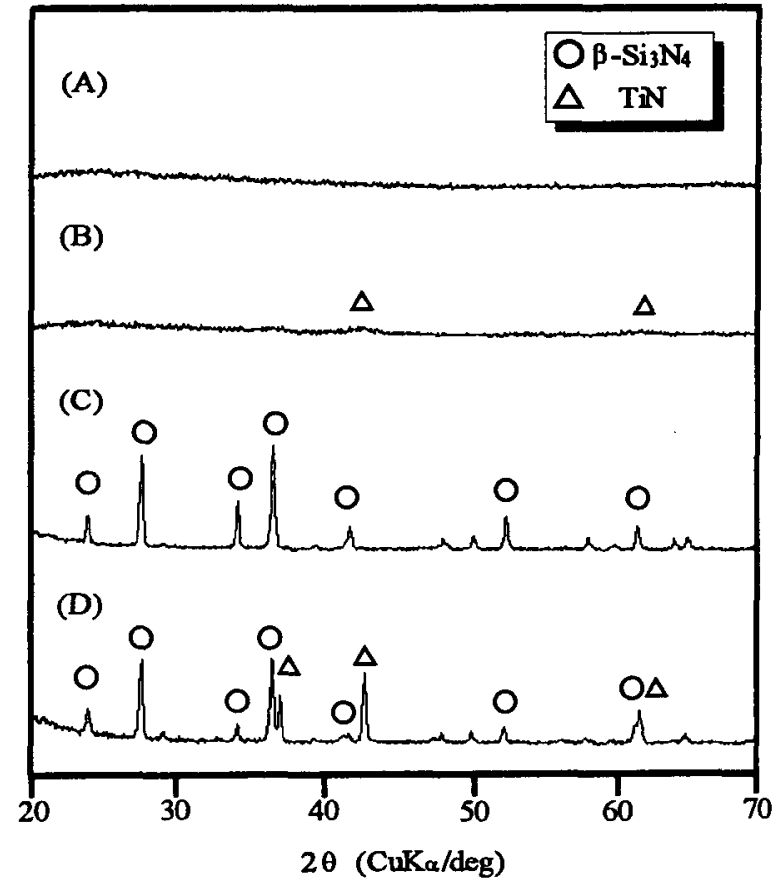

Fig.1 X-ray diffraction patterns of synthesized powders and sintered bodies. (A) $\mathrm{Si}_{3} \mathrm{~N}_{4}$ powder, (B) $\mathrm{Si}_{3} \mathrm{~N}_{4}$-TiN composite powder, (C) $\mathrm{Si}_{3} \mathrm{~N}_{4}$ sintered body, (D) $\mathrm{Si}_{3} \mathrm{~N}_{4}$-TiN sintered composite.

$\mathrm{NH}_{3}-\mathrm{H}_{2}$ system ${ }^{12)}$ and $\mathrm{TiCl}_{4}-\mathrm{NH}_{3}-\mathrm{H}_{2}$ system ${ }^{13)}$, respectively. Since the metal chlorides are highly reactive with ammonia, it is possible to form $\mathrm{Si}_{3} \mathrm{~N}_{4}$-TiN composite particles by codeposition of $\mathrm{Si}_{3} \mathrm{~N}_{4}$ and $\mathrm{TiN}$. It is known that the nitride powders prepared by the vapor phase reaction method contained excess nitrogen and hydrogen. Therefore, the synthesized powders were heat-treated for degassing. $\mathrm{Si}_{3} \mathrm{~N}_{4}$ was not crystallized at $1000-1350^{\circ} \mathrm{C}$. XRD peaks of TiN became somewhat strong after the heat treatment but were still small. Figure 1 shows a TEM photograph of $\mathrm{Si}_{3} \mathrm{~N}_{4}-$ TiN composite powder. It was confirmed by EDX analysis that $\mathrm{Si}_{3} \mathrm{~N}_{4}$ and $\mathrm{TiN}$ were mixed in very small range. Black spots observed in each particle may be assigned to TiN.

\subsection{Sintering behavior of powders}

$\mathrm{Si}_{3} \mathrm{~N}_{4}$ powder was sintered in different heating schedules as follows:

(A) the temperature was raised at $100^{\circ} \mathrm{C} / \mathrm{min}$ and kept for $2 \mathrm{~h}$ at $1800^{\circ} \mathrm{C}$,

(B) the temperature was raised at $20^{\circ} \mathrm{C} / \mathrm{min}$ and kept for $2 \mathrm{~h}$ at $1800^{\circ} \mathrm{C}$,

(C) after the sintering for $2 \mathrm{~h}$ at $1800^{\circ} \mathrm{C}$, the sintering was repeated for $2 \mathrm{~h}$ at $1850^{\circ} \mathrm{C}$ (heating rate: $100^{\circ} \mathrm{C} / \mathrm{min}$ ).

The sintering data are summarized in Table 1 . The relative densities of sintered bodies of monolithic $\mathrm{Si}_{3} \mathrm{~N}_{4}$ were 96 98\%. $\mathrm{Si}_{3} \mathrm{~N}_{4}-\mathrm{TiN}$ composite powders were all sintered with 


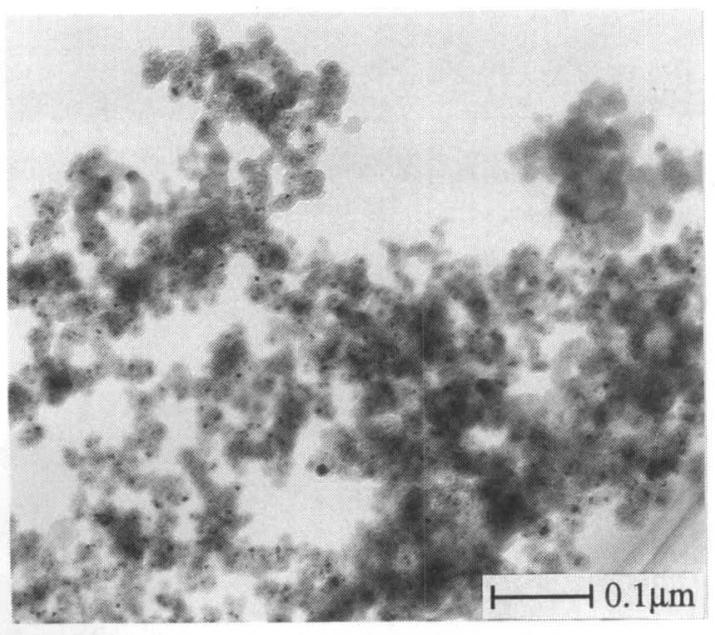

Fig.2 Particle morphology of $\mathrm{Si}_{3} \mathrm{~N}_{4}$-TiN composite powder (after heat treatment for $1 \mathrm{~h}$ at $1000^{\circ} \mathrm{C}$ in $\mathrm{N}_{2}$ ).

heating schedule (A). The relative densities of sintered composites were $94-98 \%$. The density tended to decrease with an increase in TiN content. In both monolithic and composite systems, the heat-treated powders gave slightly lower density than the as-synthesized ones. The polished surface of sintered body was analyzed by XRD. The XRD patterns are added to Fig.1. Amorphous $\mathrm{Si}_{3} \mathrm{~N}_{4}$ was crystallized into $\beta-\mathrm{Si}_{3} \mathrm{~N}_{4}$ during sintering. The peaks of TiN became strong, indicating the increase of crystallite size or crystallinity.

The microstructures of sintered bodies of as-synthesized powders are shown in Figs.3, 4 and 5. Figure 3 shows the fracture surfaces of $\mathrm{Si}_{3} \mathrm{~N}_{4}$ sintered with heating schedule (A). The sintered body of synthesized $\mathrm{Si}_{3} \mathrm{~N}_{4}$ powder had a fine-grained microstructure (Fig.3a). On the other hand, when commercial $\mathrm{Si}_{3} \mathrm{~N}_{4}$ powder was sintered under the
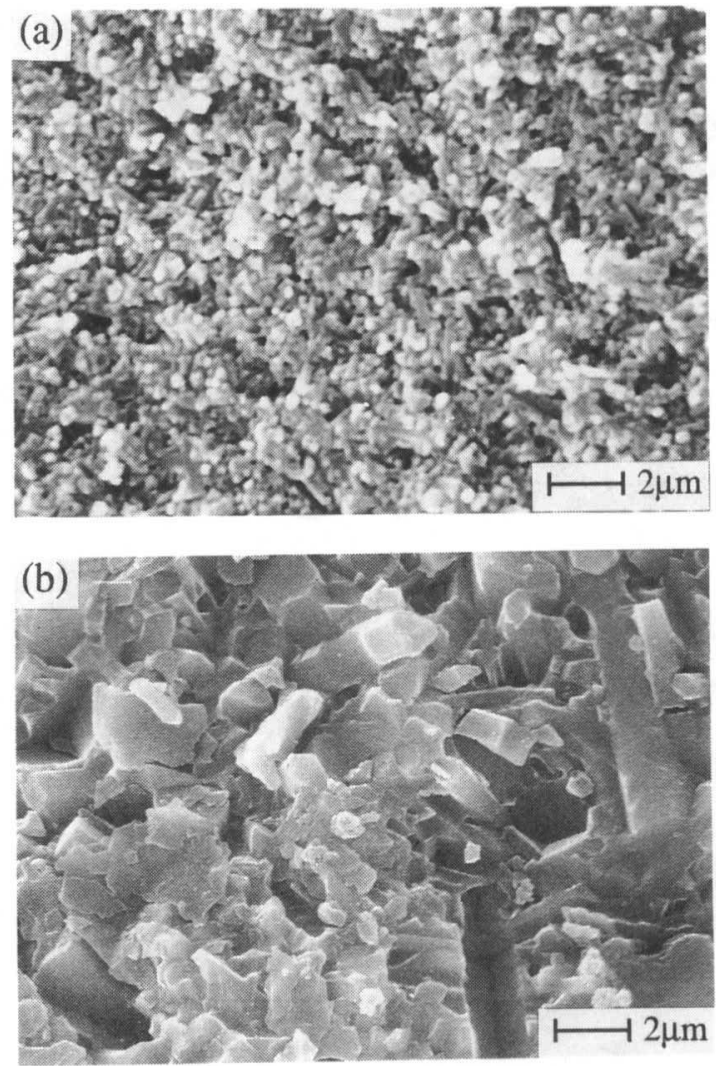

Fig.3 Fracture surfaces of $\mathrm{Si}_{3} \mathrm{~N}_{4}$ sintered with heating schedule (A). (a) synthesized $\mathrm{Si}_{3} \mathrm{~N}_{4}$ powder, (b) commercial $\mathrm{Si}_{3} \mathrm{~N}_{4}$ powder.

same condition, the grain growth was remarkable (Fig.3b), leading to growth of rod-like grains which are typically observed in $\mathrm{Si}_{3} \mathrm{~N}_{4}$ ceramics. The retardation of grain growth in synthesized $\mathrm{Si}_{3} \mathrm{~N}_{4}$ powder may be due to the small particle size and the narrow size distribution. The sintered body of synthesized $\mathrm{Si}_{3} \mathrm{~N}_{4}$ powder with heating schedule (B) also exhibited a fine-grained microstructure although small acicular grains were rarely observed. This indicates that

Table 1 Sintering data and mechanical properties of monolithic $\mathrm{Si}_{3} \mathrm{~N}_{4}$ and $\mathrm{Si}_{3} \mathrm{~N}_{4}$-TiN composites.

\begin{tabular}{|c|c|c|c|c|c|c|c|}
\hline \multirow{2}{*}{\multicolumn{2}{|c|}{ Sample }} & \multirow{2}{*}{$\begin{array}{c}\mathrm{TiN} \\
\text { (vol\%) }\end{array}$} & \multirow{2}{*}{$\begin{array}{l}\text { Heating schedule } \\
\text { for sintering }\end{array}$} & \multicolumn{4}{|c|}{ Properties of sintered body } \\
\hline & & & & $\mathrm{dr}(\%)$ & $\mathrm{Hv}(\mathrm{GPa})$ & $\mathrm{KIC}\left(\mathrm{MPa} \cdot \mathrm{m}^{1 / 2}\right)$ & $\Delta \mathrm{T}\left({ }^{\circ} \mathrm{C}\right)$ \\
\hline \multirow[t]{4}{*}{$\mathrm{Si}_{3} \mathrm{~N}_{4}$} & As-synthesized & 0 & (A) $100^{\circ} \mathrm{C} / \mathrm{min}, 1800^{\circ} \mathrm{C}(2 \mathrm{~h})$ & 97.8 & 18.2 & 6.0 & 600 \\
\hline & & 0 & (B) $20^{\circ} \mathrm{C} / \mathrm{min}, 1800^{\circ} \mathrm{C}(2 \mathrm{~h})$ & 98.0 & - & - & - \\
\hline & & 0 & (C) $1800^{\circ} \mathrm{C}(2 \mathrm{~h})+1850^{\circ} \mathrm{C}(2 \mathrm{~h})$ & 97.5 & 17.0 & 6.4 & - \\
\hline & Heat-treated & 0 & (A) $100^{\circ} \mathrm{C} / \mathrm{min}, 1800^{\circ} \mathrm{C}(2 \mathrm{~h})$ & 96.9 & 17.4 & 6.0 & 650 \\
\hline \multirow{4}{*}{$\begin{array}{l}\mathrm{Si}_{3} \mathrm{~N}_{4} \\
-\mathrm{TiN}\end{array}$} & As-synthesized & 8 & (A) $100^{\circ} \mathrm{C} / \mathrm{min}, 1800^{\circ} \mathrm{C}(2 \mathrm{~h})$ & 98.1 & 17.7 & 6.5 & 490 \\
\hline & & 18 & (A) $100^{\circ} \mathrm{C} / \mathrm{min}, 1800^{\circ} \mathrm{C}(2 \mathrm{~h})$ & 95.1 & 17.1 & 6.5 & 460 \\
\hline & Heat-treated & 10 & (A) $100^{\circ} \mathrm{C} / \mathrm{min}, 1800^{\circ} \mathrm{C}(2 \mathrm{~h})$ & 96.7 & 16.7 & 6.1 & 530 \\
\hline & & 18 & (A) $100^{\circ} \mathrm{C} / \mathrm{min}, 1800^{\circ} \mathrm{C}(2 \mathrm{~h})$ & 94.6 & 15.9 & 6.0 & 460 \\
\hline
\end{tabular}

Heat-treatment : $1350^{\circ} \mathrm{C}, 2 \mathrm{~h}$ in N2. dr : relative density. $\mathrm{Hv}$ : Vickers hardness. KIC : fracture toughness.

$\Delta \mathrm{T}$ : critical temperature difference for crack initiation. 

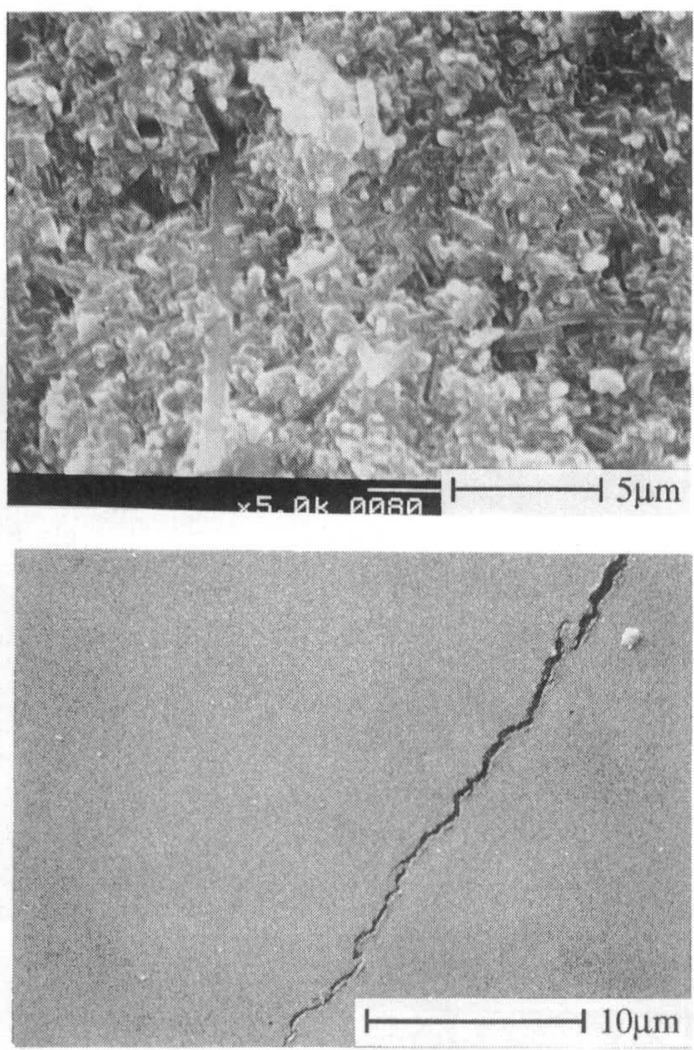

Fig.4 Fracture and polished surfaces of sintered body of synthesized $\mathrm{Si}_{3} \mathrm{~N}_{4}$ powder with heating schedule (C). The crack was propagated by the Vickers indentation.

the effect of heating rate was small. Figure 4a shows the microstructure of sintered body of synthesized $\mathrm{Si}_{3} \mathrm{~N}_{4}$ powder with heating schedule (C). In this specimen, rod-like grains were observed in fine-grained matrix. This was caused by repeated sintering at higher temperature $\left(1850^{\circ} \mathrm{C}\right)$. When the synthesized powders were directly heated up to 1850 ${ }^{\circ} \mathrm{C}, \mathrm{Si}_{3} \mathrm{~N}_{4}$ partially decomposed. Fine amorphous $\mathrm{Si}_{3} \mathrm{~N}_{4}$ powder seemed to be unstable under the present sintering atmosphere $\left(1 \mathrm{~atm} \mathrm{~N}_{2}\right)$. Therefore, the preliminary sintering was useful to sinter the fine amorphous powder at the high temperature. Figure 5 a shows the microstructure of $\mathrm{Si}_{3} \mathrm{~N}_{4-}$ TiN composite sintered with heating schedule (A). In this composite system, rod-like grains were observed even at $1800^{\circ} \mathrm{C}$. It has been suggested that fine $\mathrm{TiN}$ inclusions worked as nuclei accelerating the growth of $\mathrm{Si}_{3} \mathrm{~N}_{4}$ rod-like grains in liquid phase sintering ${ }^{14)}$. In the present work also, $\mathrm{Si}_{3} \mathrm{~N}_{4}$ seemed to grow in the same mechanism.

The sintered body of heat-treated $\mathrm{Si}_{3} \mathrm{~N}_{4}$ powder also had a fine-grained microstructure although several rod-like grains were observed even at $1800^{\circ} \mathrm{C}$. On the other hand, rod-like grains scarcely formed in the heat-treated powder of $\mathrm{Si}_{3} \mathrm{~N}_{4}$-TiN system. The reason for the difference in sintered texture between as-synthesized and heat-treated
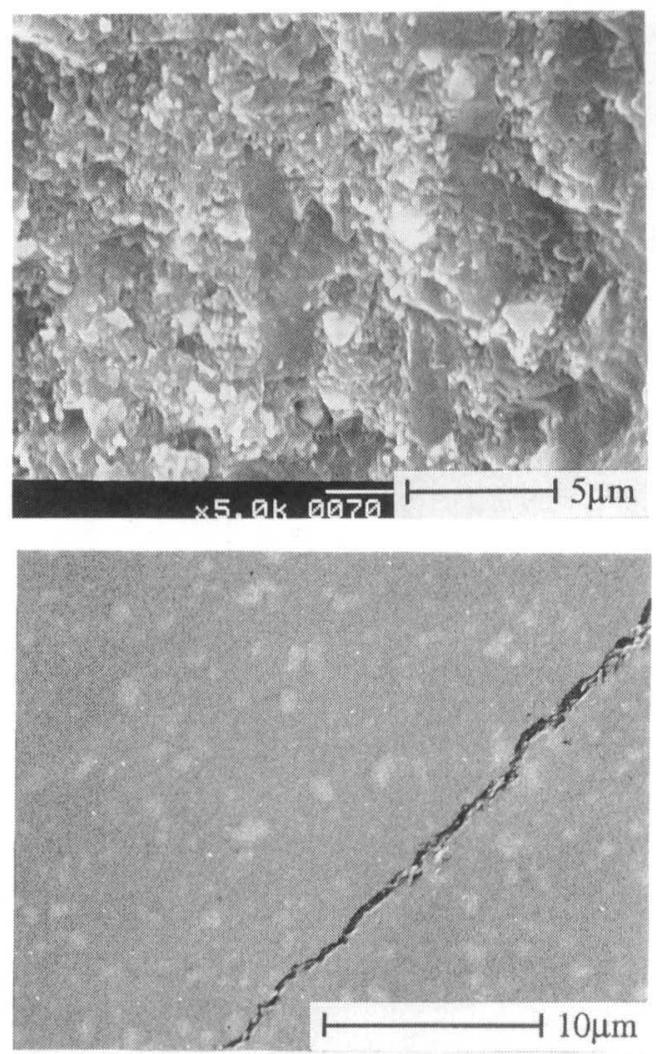

Fig.5 Fracture and polished surfaces of sintered body of $\mathrm{Si}_{3} \mathrm{~N}_{4}-\mathrm{TiN}$ composite powder (heating schedule (A)). The crack was propagated by the Vickers indentation.

powders was obscure. Although the fine particles slightly grew by heat treatment at $1350^{\circ} \mathrm{C}$, the powders were still fine. The heat treatment might have increased the oxygen content by accumulation of impurity oxygen in $\mathrm{N}_{2}$ stream. 3.3 Mechanical properties of sintered bodies

The data of mechanical properties are added to Table 1. In the sintered bodies of as-synthesized $\mathrm{Si}_{3} \mathrm{~N}_{4}$ powder, the hardness was 17-18GPa, the fracture toughness was 6.0$6.4 \mathrm{MPa} \cdot \mathrm{m}^{1 / 2}$ and the critical temperature difference for crack initiation was about $600^{\circ} \mathrm{C}$. It should be noted that the fracture toughness was increased by repeated sintering at $1850^{\circ} \mathrm{C}$. Figure $4 \mathrm{~b}$ shows the polished surface with a crack propagated by the Vickers indentation. The zigzagged crack means the crack deflection by rod-like grains contained in this specimen. This is the reason for the increase in fracture toughness.

The mechanical properties of sintered bodies of assynthesized $\mathrm{Si}_{3} \mathrm{~N}_{4}$-TiN composite powders are illustrated as a function of TiN content in Fig.6. The hardness slightly decreased with increasing TiN content because of the decrease in sintered density. On the other hand, the fracture toughness was increased by TiN addition. Figure $5 \mathrm{~b}$ shows the polished surface with a Vickers indentation crack. 


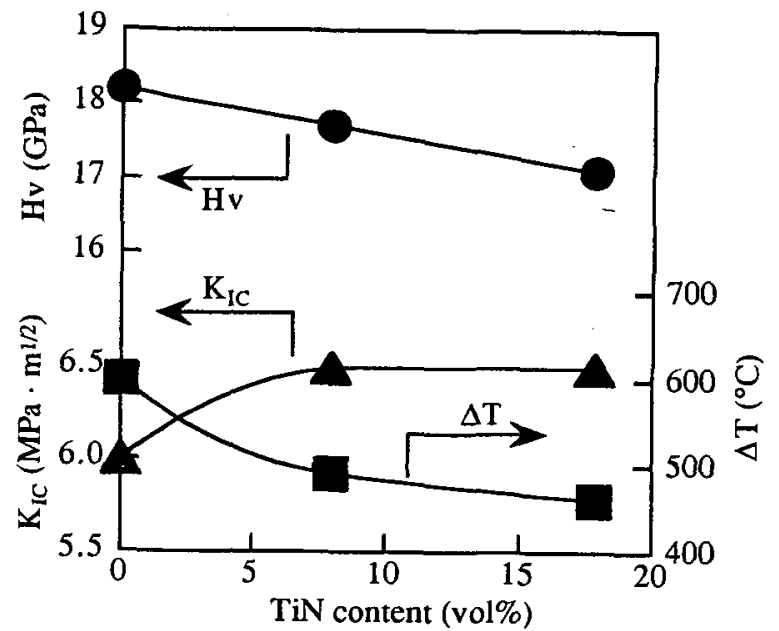

Fig.6 Variation of hardness (Hv), fracture toughness $\left(\mathrm{K}_{\mathrm{IC}}\right)$ and critical temperature difference for crack initiation $(\Delta \mathrm{T})$ with TiN content in $\mathrm{Si}_{3} \mathrm{~N}_{4}-\mathrm{TiN}$ system.

Whitish particles were assigned to TiN. Although TiN particles grew maximally up to $2 \mu \mathrm{m}$, the composite included many fine TiN particles with the size below $1 \mu \mathrm{m}$. This suggests that $\mathrm{Si}_{3} \mathrm{~N}_{4}$-TiN composite powder may be useful for fabricating $\mathrm{Si}_{3} \mathrm{~N}_{4}$-TiN nanocomposites. The high fracture toughness of the composite may be due to crack deflection as seen in Fig.5b. The crack deflection may be caused by rod-like grains formed by inclusion of fine TiN particles, and residual stresses evolved from the difference in thermal expansion coefficient between $\mathrm{Si}_{3} \mathrm{~N}_{4}\left(2.8 \times 10^{-6} \%\right.$ $\left.{ }^{\circ} \mathrm{C}\right)$ and $\operatorname{TiN}\left(9.3 \times 10^{-6} /{ }^{\circ} \mathrm{C}\right)^{15}$. As described above, the addition of TiN was effective to improve the fracture toughness. However, the thermal shock resistance was lowered by TiN addition because the gap in thermal expansion coefficient also brings an opposite effect, that is, rupture by thermal stress during quenching.

The mechanical properties of some specimens in Table 1 could not be evaluated because many pores remained on the surface. This may be due to gas evolution during sintering. Although the synthesized powders were heattreated to improve the sinterability, the sintered density was decreased. The sintered bodies of heat-treated $\mathrm{Si}_{3} \mathrm{~N}_{4}$-TiN powders had low hardness and fracture toughness because of the low density. On the other hand, the thermal shock resistance was somewhat high in the heat-treated powders when TiN content was zero or small. This may be due to the absorption of thermal stress by small pores.

\section{CONCLUSION}

Fine powders of $\mathrm{Si}_{3} \mathrm{~N}_{4}$-TiN system can be prepared by the vapor phase reaction method, in which $\mathrm{Si}_{3} \mathrm{~N}_{4}$ is in the amorphous state and TiN has very small particle size or low crystallinity. $\beta-\mathrm{Si}_{3} \mathrm{~N}_{4}$ and TiN clearly appear during sintering. The sintered bodies have fine-grained microstructures. The increase of sintering temperature stimulates the growth of rod-like $\mathrm{Si}_{3} \mathrm{~N}_{4}$ grains, leading to increase in the fracture toughness. It is possible to fabricate $\mathrm{Si}_{3} \mathrm{~N}_{4}$-TiN nanocomposites by sintering of the composite powders. The TiN addition stimulates the rod-like grain growth even at a low temperature. The $\mathrm{Si}_{3} \mathrm{~N}_{4}$ - $\mathrm{TiN}$ composites have a high fracture toughness although the thermal shock resistance is decreased. The problem in use of the fine powders is that the sintered bodies are not densified up to the full density. The improvement of sinterability is required for achieving more excellent mechanical properties.

\section{ACKNOLEDGEMENT}

This work has been entrusted by NEDO as part of the Synergy Ceramics Project under the Industrial Science and Technology Frontier (ISTF) Program promoted by AIST, MITI, Japan.

\section{REFERENCES}

1) K.Niihara: "New Design Concept of Structural Ceramics-Ceramic Nanocomposites", J. Ceram. Soc. Japan, 99(1991)974-982.

2) J.Hojo, H.Maeda and A.Kato: "Preparation of

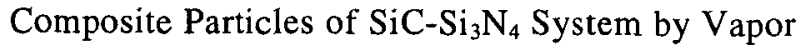
Reaction Method", Yogyo-Kyokai-Shi, 95(1987)4549.

3) J.Hojo, M.Aratani and A.Kato: "Vapor Phase Synthesis and Sintering of SiC-BN Composite Particles", Ceramic Transactions Vol.22, S.Hirano, G.L.Messing and H. Hausner ed., American Ceramic Society, (1991)121-126.

4) J.Hojo: "Fabrication of Nanocomposite Particles by Vapor Phase Reaction and Its Applications", Proc. Fourth Nisshin Engineering Particle Technology International Seminar, K.Niihara ed., Osaka, Nisshin Engineering Co. Ltd., (1995)9-17.

5) J.Hojo: "Sintering Behavior of Ultrafine Silicon Carbide Powder", Silicon Carbide Ceramics-1, S.Somiya and Y.Inomata ed., Elsevier, (1991)149-168.

6) J.Hojo, M.Aratani and A.Kato: "Preparation of SiCBN Ceramics Using Fine Composite Particles", EuroCeramics II, G.Ziegler and H.Hausner ed., Deutsche Keramische Gesellschaft e.V.(1991)1505-1509.

7) J.Hojo, K.Kishi and S.Umebayashi: "Nanocomposites Obtained from Ultrafine Composite Particles", Ceramic Transactions Vol.51, H.Hausner, G.L.Messing and 
S.Hirano ed., American Ceramic Society, (1995)597601.

8) Y.Yasutomi, K.Nakamura, M.Sobue and Y.Kubo: "Development and Characterization of ElectroConductive $\mathrm{Si}_{3} \mathrm{~N}_{4}$ Bonded TiN Ceramics", J. Ceram. Soc. Japan, 97(1989)148-154.

9) T.Nagaoka, M.Yasuoka, K.Hirao and S.Kanzaki: "Effects of TiN Particle Size on Mechanical Properties of $\mathrm{Si}_{3} \mathrm{~N}_{4} / \mathrm{TiN}$ Particulate Composites", J. Ceram. Soc. Japan, 100(1992)617-620.

10) K.Ueno, T.Inoue, S.Sodeoka, M.Suzuki, H.Ishikawa, K.Uchiyama and T.Inui: " $\mathrm{Si}_{3} \mathrm{~N}_{4}$-Matrix Composite with TiN Particles Formed by In-situ Reaction", J. Ceram. Soc. Japan, 105(1997)304-307.

11) K.Niihara, R.Morena and D.P.H.Hasselman: "Evaluation of $\mathrm{K}_{\mathrm{IC}}$ of Brittle Solids by the Indentation
Method with Low Crack-to-Indent Ratios", J. Mater. Sci. Letters, 1(1982)13-16.

12) A.Kato, Y.Ono, S.Kawazoe and I.Mochida: "Finely Divided Silicon Nitride by Vapor Phase Reaction between Silicon Tetrachloride and Ammonia", YogyoKyokai-Shi, 80(1972)114-120.

13) A.Kato, M.Iwata, J.Hojo and M.Nagano: "Fine Titanium Nitride Powders by the Vapor Phase Reaction of $\mathrm{TiCl}_{4}-\mathrm{NH}_{3}-\mathrm{H}_{2}-\mathrm{N}_{2}$ System", Yogyo-Kyokai-Shi, 83 (1975)453-459.

14) Joint Research Consortium of Synergy Ceramics: Research and Development of Synergy Ceramics, Fine Ceramics Research Association, (1996) 325.

15) Y.Sakurai, M.Koizumi and C.Matsumoto: New Ceramics (Materials and Its Applications), Nikkan Kogyo, (1977)251. 